Янко Рамач

Универзитет у Новим Садзе

Филозофски факултет

Оддзелєнє за русинистику

janko.ramac@ff.uns.ac.rs
УДК 821.161.2(497.113)(=124.1)"17/18"

https://doi.org/10.18485/slavistika.2020.24.2.30

прегледни рад

примљено 26.08.2020.

прихваћено за штампу 18.09.2020.

\title{
ЕПИСТОЛАРНЕ НАШЛЇДСТВО РУСКИХ СВЯЩЕНЇКОХ У БАЧКИ НА ЛАТИНСКИМ ЯЗИКУ У ДРУГЕЙ ПОЛОВКИ ХVIII И НА ПОЧАТКУ ХІХ ВИКА
}

Руснаци грекокатолїки, котри ше коло половки XVIII вику почали присельовац до Бачки, од 1751. року у церковно-правним поглядзе були под юрисдикцию римокатолїцкей Калочскей архиепископиї, а 1777. року за нїх и за грекокатолїкох у Горватскей основана Крижевска епархия. Зоз представителями церковних и державних власцох руски священїки официйну преписку водзели найчастейше на латиским язику. У церкви и церковних обрядох хасновали церковнославянски язик. У директним контакту з вирнима хасновали руску народну бешеду, а у медзисобней приватней преписки у XVIII и на початку XIX вика у медзисобну приватну преписку водзели на латинским язику. У статї преанализуєме змист часци зачуваней преписки на латински язику, оценююци єй значенє як историйного жридла.

Ключни слова: Руснаци у Южней Угорскей, Петро Копчаї, Лука Сташински, Янко Копчаї ст., Янко Копчаї мл., грекокатолїки, приватна преписка, латински язик, руски язик.

Ruthenian Greek Catholics, who started settling Bačka around the mid-18th century, were from 1751, in ecclesiastical and legal terms, under the jurisdiction of the Roman Catholic Archdiocese of Kalocsa, whereas in 1777 for them, and for the Greek Catholics in Croatia, the Diocese of Križevci was founded. Official correspondence of Ruthenian priests with the representatives of the church and state authorities was mostly in Latin. In church and church rites they used the Church Slavonic language. In direct contact with the faithful they used the Ruthenian vernacular, but their mutual private correspondence in the 18th and at the beginning of the 19th centuries was in Latin. In this article we will analyze the content of a piece of preserved correspondence in the Latin language, assessing its significance as a historical source.

Keywords: Ruthenians in Southern Hungary, Petro Kopcaji, Luka Stasinski, Janko Kopcaji Sr, Janko Kopcaji Jr, Greek Catholics, private correspondence, Latin language, Ruthenian language.

У потерашнїх виглєдованьох историї язика Руснацох у Южней Угорскей/ Югославиї Гнатюково записи їх фолклору направени у Керестуре и Коцуре 1897. року (Гнатюк 1985; Гнатюк 1986а; Гнатюк 1886б; Гнатюк 1986; Гнатюк $1988)$ вецей прицаговали увагу як други значни жридла - рукописни хронїки и зборнїки духовней прози и поезиї, на историографске, литературно-културне и лингвистичне значенє котрих указали перше українски науковци В. Гнатюк (Гнатюк 1898: 51) и Иван Франко (Франко 1899: т. II 74-98, 191-196, 211-220, 237-240, 369-370 ; Франко 1906: т. IV, 80, 234-235, 357-360), а вец и Михайло Ковач (Ковач 1973, 1977), Юлиян Тамаш (Тамаш 1997: 61-69), Янко Рамач (Рамач 2010, 2011, 2016 2018), и котри часточно наводзели лингвисти Юлиян Рамач (Рамач 2002: 534-554) и Александер Дуличенко (Дуличенко 2002: 16-31). Правда, Анамария Рамач Фурман пошвецела єдну роботу лингвистичней анализи єдного рукописного зборнїка (Рамач Фурман 2019). 
У тей нагоди нашо интересованє прицагує епистоларне нашлїдство руских священїкох на латинским язику (з конца XVIII - початку XIX в.) пре факт же шицки вони у каждодньовей бешеди хасновали руски народни язик, а у ридких нагодох и писали на вариянтох тедишнього кнїжного русинского язика у Угорскей. Як приклад того язика публиковане писмо керестурского пароха Георгия Росия з 1756. Року, писане приятельови архимандритови василиянских манастирох у Угорскей Янкови Скрипкови (Удвари 1989). У приватней медзисобней преписки священїки частейше хасновали латински язик, до хторого дакеди уруцовали слова або и цали виреченя на руским/русинским язику.

Гавриїл Костельник у своєй хронїки Руского Керестура (Костельник, 1998) перши обрацел увагу на факт, же ше керестурски парох Петро Копчаї (17531819) (Миз 2016: 183-184), перше як штредньошколєц и студент богословиї, а вец и як керестурски парох, зоз своїм старшим братом Янком Копчайом, священїком Мукачевскей епархиї (Lucskay 1992: 151-152), дописовал на латинским язику, а познєйше так исто и зоз своїм сином Янком (1790-1844) (Миз 2016: 184-185), кед тот бул на студийох богословиї у Бечу. После того анї у историографиї анї у лингвистики тому питаню нє пошвецована векша увага и нє предлужени виглєдованя у тим напряме.

У архиви грекокатолїцкей парохиї у Руским Керестуре (АПРК) окрем службених документох и преписки зачувана и часц приватней преписки даєдних священїкох котри ту службовали на концу XVIII и на початку XIX вика. Вельку часц приватного епистоларного нашлїдства 3 того часу зме препатрели и попробуєме тот жридлови материял систематизовац, анализовац и оценїц його значенє за виглєдованє церковно-религийного, образовного, социялного и привредного живота Руснацох у Южней Угорскей у тим чаше. Найвекша часц зачуваней преписки - писма Янка Копчая ст., священїка Мукачевскей епархиї, младшому братови Петрови и лєм даскельо концепти Петрових писмох братови Янкови, вкупно коло 30. Тота преписка дава вельо податки о живоце Янка Капчая на парохийох Мукачевскей епархиї, о одношеньох и обставинох у тей епархиї, а менєй з нєй мож дознац и створиц подполнєйшу слику о подійох и обставинох у Бачки и конкретно у Керестуре. Ту ше находза и седем писма коцурского пароха Луки Сташинского (Миз 2016: 305-306) Петрови Копчайови и два концепти Петрових писмох/одвитох Сташинскому. Ту зачувани три писма Петра Копчая синови Янкови, и три синово писма оцови. Нє цалком ясне як ше у тим архиве нашли даскельо писма коцурского пароха Л. Сташинкого, од тих два котри писал богословом зоз своєй парохиї, як и одвити на нїх. За даскельо писма зме не могли утвердзиц хто их писал або кому и кеди су точно писани.

Латински язик спатраних писмох нє будземе анализовац прето же ше нє чувствуєме за тото досц компетентни, а у тей нагоди то анї нє циль. Тримаме же доцильнєйше пробовац найсц одвит прецо праве латински язик доминовал у спомнутих писмох, кед познате же и адресанти и адресани бешедовали и добре знали писац и на тедишнїм русинским односно карпаторусинским чи вариянти церковнославянского язика котри ше у тим чаше хасновал як литературна форма медзи Русинами Мукачвскей епархиї.

На питанє прецо Янко Копчаї младшому братови Петрови, док тот бул перше у гимназиї у Надь-Каролю (1774-1779. р., вкупно 5 писма), а вец студент у 
семинариї Св. Варвари у Бечу, (1780-1782. р., вкупно 7 писма) писал писма по латински мож дац вецей одвити, алє главни причини, по нашим думаню, практичней природи. Свяшенїк Янко Копчаї, хтори, як видно з тих писмох, у велькей мири зношел трошки школованя младношо брата Петра, пишуци писма на латинским язику вироятно мал намиру и на таки способ му помогнуц усовершовац класични язик и учиц манири висловйованя у преписки. Може то покус випатрац и як мода односно способ доказованя образованосци або припадносци образованому швету и висшому пасму дружтва, дзе ше грекокатолїцке священство ословйовало з Reverendus/Reverendissimus.

Праве у чаше кед Янко Копчаї писал тоти писма братови Петрови, на чолє Мукачевскей епархиї бул епископ Андрей Бачински (1732-1809), котри укладал вельо усиловносци же би шицки священїки його епархиї знали русински язик, же би добре знали кирилку и же би з вирнима контактовали на народним язику, наглашуюци же русински язик и кирилка значни фактори за чуванє националного идентитету Русинох у Угорскей. Спомнути пастирски писма шведоча о моцнєню процеса мадяризациї русинского грекокатолїцкого священства, котра ше у значней мири окончовала у системи школованя (Шлепецький 1967; Удвари 1991, 2002). Медзитим, питанє язика комуникациї русинского священства у Мукачевскей епархиї з висшу церковну власцу, медзи собу и з вирнима було досц зложене. Правда же ше у конфесийних школох учело на народним русинским язику, алє тоти школи лєдво давали основи писменосци: школяре у нїх научели читац и писац. У тим чаше лєм ридки поєдинци предлужовали школованє и одходзели до латинских школох, а там вецей нє учели русински язик, а нє учели го анї на студийох филозофиї и теологиї (Удвари 1992-1993, 2002). Прето розумлїве же священїки тей епархиї вельо лєпше у писаню пановали зоз

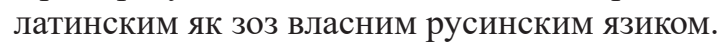

Петро Копчаї и Лука Сташинки, обидвоме по походзєню зоз Закарпат’я, уж як священїки у Бачки, Петро парох у Керестуре, Лука - у Коцуре, сушедове по парохийох, а гу тому ище и кумове, медзисобну приватну кореспонденцию углавним водзели на латинским язику. Медзитим, у їх писмох єст интерполациї, слова, вислови а часто и виреченя и на русинским язику. Зачуване єдно писмо Сташинского кумови Копчайови на русинским язику (АПРК: Коцур, 22. 06. 1795).

Петро Копчаї писал писма синови Янкови на латинским, а так му и син одвитовал. Лєм у даєдних писмох Петро уруцує даєдно руске слово, алє пише 3 латиницу, а Янко у таких случайох писал и з кирилку.

Препатрени приватни писма даваю вельо податки насампредз о приватним живоце адресантох и адресатох. У вчасней преписки Янка Копчая з братом Петром, док тот бул у стреднєй школи у Вельким Варадинє (1774-1779), а познєйше студент теологиї у семинариї Св. Варвари у Бечу (1780-1782), зачувани податки о його школованю котре преходзело у нєвигодних материялних обставинох. Янко нєпреривно совитовал и опоминал младшого брата же би пилно учел и так ше рихтал за священїцке поволанє, даваюци му до знаня же чежко видвоює пенєж за його школованє (АПРК: Вельки Варадин, 28. 03. 1774; Дорог, 27. 10. 1781). У школи и на студийох Петро ше зочовал з почежкосцами адаптованя худобного хлапца/легиня 3 провинциї у векшим городским стред- 
ку и часто писал о нєприємносцох котри доживйовал як припаднїк нїзшого пасма дружтва. Кед ше поносовал братови же го даєдни понїжую пре його нїзке походзенє - „(...) scribas insuper te a quibusdam male tractari...”, брат му совитує же би то сцерпезлїво подношел и же би паметал же чеснота квици походзенє/ род, а нє походзєнє чесноту - „(...) quia virtus natales ornat, non natales virtutem“ (АПРК, Дорог, 31. 01. 1781). Окрем того, тих рокох Янко писал младшому братови и о своїх священїцких обовязкох и проблемох, о своїм здравю, о здравю родичох. У писме братови Петрови у октобре 1781. року пише же мац уж тидзень при ньому, старенька є и хора, алє ше сце врациц дому - "Dilectam matrem ab hebdomada hic apud me habeo, jam nimis senem, quae tamen patriam repetere anhelat"“ (АПРК: Дорог, 27. 10. 1781).

Найвекша часц преписки братох Копчайох походзи з часу кед Петро 1783. року бул намесцени перше за управителя, а нєодлуга потим за пароха у Керестуре, по 1808. рок (вкупно коло 20 писма). Главни теми тих писмох їх приватни живот и живот найблїзшей родзини, питаня з їх священїцкого дїлокруга и ширше социялни и привредни обставини.

По снованю Крижевскей епархиї, кед крижевски епископ Василий Божичкович (1759-1785) одлучел превжац даскелїх питомцох Русинох з Мукачевскей епархиї же би так обезпечел священїкох за парохиї Руснацох у Бачки, Я. Копчаї такой совитовал братови Петрови же би ше приявел (АПРК: Дорог, 29. 07. 1779), наздаваюци же Крижевска епархия будзе зношиц голєм часц трошкох його студийох, а цо найважнєйше, на концу му будзе обезпечена парохия. Познєйше, кед Петро пред пошвецаньом одлучел присц до завичаю оженїц ше, старши брат го спозорйовал же анї єдна дзивка нє зосце пойсц так далєко до нєпознатого краю, до Бачки, и совитовал му же би себе нашол пару у Горватскей або медзи Руснацами у Бачки - „, uxorem seu Croatam, seu Ruthenam Bacsiensem duc“" (АПРК: Дорог, 10. 09. 1782). Петро нє послухал брата - оженєл ше з дзивку зоз завичаю, а нєодлуга ше указало же Янково спозорйованя були далєковидни. Уж 1783. року Петро у писмох братови Янкови спомина же його панїматка Ана барз жалї за завичайом, за Венчельовом, та ше му познєйше брат пита чи ище вше жалї за Венчельовом - (...) „Quid tua Anna? Num luget adhuc Vencselo?“ (АПРК: 9. 09. 1783), и далєй констатує: "Кед так, та жада єгіпетску цібулю "caepas Aegypti“" место мані у пустинї” (Костельник 1998: 125.). Як старши брат, Янко сцел помогнуц Петрови та му совитовал же би зоз супругу/панїматку дакус строгше поступал, кед ше сама нє може стримац од алкоголу, а кед треба, же би указал и корбач, та озда лєпше зрозуми - "mastygem ostenta, forte sapiet" (АПРК, Дорог, 17. 02. 1784). Благи Петро себе нїяк нє могол дац ради з панїматку Ана котра вше баржей подлєговала алкоголу. Янко нє бул оженєти, а випатра же нє мал найлєпше думанє о женох, бо у писме братови пише же нєдобра жена чежки криж за чловека - "Gravis crux mala uxor", и дава му совит котри би ше нє мало обчековац од священїка: кед нїч нє помага и вона же нє злєпша, Петрови нє остава друге лєм же би ю спаковал до коча и послал до завичаю до родичох - "...quod eam sis ad currum positurus et ad Parentes remissurum nisi mores correxerit" (АПРК: Шаторя Уйгель, 21. 07. 1797). Нажаль, з панїматку оставало по старим, або ишло и на горше, та ше Петро нєпреривно поносовал старшому братови на свойо турботи. У єдним писме Янко пише братови же достал од ньо- 
го писмо котре го барз розжалєло. Нє нашли зме анї концепт писма та нє ясне цо сущносц того знємиреня, алє мож предпоставиц же ше Петро знова поносовал на панїматку Ану, бо му брат совитує же кед ше Ана наисце нє може пременїц, же би ю одплашел до родичох, же би му нє знїщела чесц, бо лєпше буц без жени, як без чесци, - "ut corrigi non possit, pelle illam, mitas eam ad Parentes suos ne ultro quoque honori tuo noceat: potius absque uxore sis, quam absque honorem" (АПРК: Уйгель, 22. 03. 1798).

У писмох ше браца Янко и Петро вецейраз догваряли же нащивя єден другого, алє нєт ясни шлїди о тим же то було реализоване. Янко ше бал и за вихованє и школованє Петрового сина Янка, прешвечени же го мац алкоголичарка може лєм погубиц, та у вецей нагодох модлєл брата же би сина послал гу ньому и же ше вон будзе старац о його школованю (АПРК: Уйгель, 22. 03. 1798; Уйгель, 3. 08. 1798; Уйгель, 23. 12. 1798; Ужгород, 8. 05. 1802), алє и тото нє було витворене.

Янко барз часто писал Петрови о родичох и о блїзшей родзини, о братох и шестри, о и їх дзецох. Як наводзел у писмох, кажди рок им давал жита и друге цо могол (АПРК: Дорог, 1. 08. 1785), а вельо помагал и у школованю їх дзецох (АПРК: Дорог, 17. 11. 1792; Уйгель, 6. 10. 1797). Вецейраз писал братови Петрови же зоз своїх малих приходох чежко шицко тото може посцигнуц, та го аж и модлєл же би голєм з часци превжал трошки школованя даєдного сина своїх братох або шестри (АПРК: Дорог, 1. 08. 1785), алє, кельо з писмох познате, анї тото нє було реализоване.

Янко часто писал Петрови о своїх финансийних проблемох, котри з єдного боку були пошлїдок худобства вирних у парохийох у котрих службовал, а пре нєродни роки и части елементарни нєпогоди анї з парохийного газдовства нє могол достац значнєйши приходи. Так 1784. року писал же ма досц жита на предай, алє цена була слаба та нє сцел предавац, а пре нєдостаток покарми за овци мушел драго куповац шено (АПРК: Дорог, 17. 02. 1784.

Вєшенї 1786. року Янко винчовал Петрови родзенє сина и источашнє ше поносовал же оберачка грозна була слаба та будзе мало вина. Шнїг барз вчас спаднул та ше анї пошац нє сцигло и хто зна як будзе нарок (АПРК: Дорог, 11. 11. 1786). У априлу 1795. року писал же у краю велька бида, жима, єдзенє барз драге (АПРК: Надь Селеш, 17. 04. 1795). Добре замерковал Симеон Пишчевич у своїх Mемоарох, кед преходзел през тоти худобни карпатски краї у котрих жили Русини, же там людзе нє маю цо єсц и за статок нєт покарми и кед добри рок, а дзе ище кед ше нарошую даскельо нєродни роки (Пишчевић: 369).

Пре чежке материялне положенє Янко на вецей заводи жичал пенєж од младшого брата Петра (АНПР: Уйгель, 23. 12. 1798; Уйгель, 9. 06. 1801; Костельник, 1998: 50), цо шведочи же керестурски парох у тим чаше жил у лєпших материялних обставинох. А факт, же Руснаци грекокатолїки у Керестуре и Коцуре як коморски поданїки у тим чаше жили у вельо вигоднєйших привредних и социялних обставинох як їх сонароднїки у краю з котрого ше вони ту преселєли (Рамач 2007: 75-104). Медзитим, у тим чаше, як шведочи тота преписка, пенєж нє було лєгко послац: випатра же то було лєгчєйше, сигурнєйше и туньше зробиц по довирлївих людзох котри путовали, як по официйней пошти, дзе ше пенєж нєридко знал "затрациц" (Костельник 1998: 50; АПРК: Ужгород, 19. 04. 1808). 
У писмох братови Янко часто писал о обставинох у Мукачевскей епархиї, о одношеньох медзи священством, о їх змаганю за лєпши парохиї, поготов за висши званя и достоїнства, цо вше було провадзене $з$ векшима приходами. Учашнїки у тих змаганьох за посцигованє циля часто забували нє лєм на основни постулати священїцкого живота алє и на морални норми и були порихтани на рижни интриги (АПРК: Дорог, 25. 03. 1790; Дорог, 17. 03. 1792; Уйгель, 3. 10. 1800; Уйгель, 20. 01. 1801; Lucskay 1992: 109-153).

Петро, як мож заключиц зоз писмох, нє одбивал пожичиц пенєж старшому братови, знаюци у яких обставинох тот жиє, алє вироятно и чувствуюци длуство чи моралну обовязку голєм 3 часци ше оддлужиц братови котри му вельо помогнул у школованю, та и пре факт же Янко остал у краю з родичами и своїма братами и шестру, котрим материялно помагал кельо и як могол.

3 преписки коцурского пароха Л. Сташинского и П. Копчая (нашли зме 9 оригинални писма Л. Сташинского и лєм даєден концепт писма П. Копчая Сташинскому), мож вельо дознац о їх приватних контактох, о фамилийним живоце, о родзеню и кресценю їх дзецох. Так Сташински, кед ше му народзел син, истого дня о тим повидомює П. Копчая и волал го же би такой пришол на кресценє: "Juliana mea hodie hora matutina 5-a (...) tulit mihi in lucem feliciter filiolu, quem illico hodie sacro fonte ablui cupio, proinde humillime rogo, dignet se pro baptisantese humilire“ (АПРК: Коцур, 24. 11. 1791), а кед хлапчик о даскельо мешаци умар, поволує Патра на хованє: „Denique crudelis ila mors demessuit gratissimum tenellum flosculum meum. (...) Corpusculum vero ejus tumulo condere volumus cras hora nona aut decima“" (АПРК: 22. 04. 1792). У даєдних писмох ше догваряли и о ришовню актуелних проблемох, котри под’єднак мучели обидвох парохох, як наприклад, отримованє традицийних прадкох односно сходох младежи. Сташински у писме Копчайови вєшенї 1783. року наводзи же пред даскелїма роками власци забранєли отримованє ноцних сходох такволаних прадкох - "nоcturnae conventriculae (vulgo pradkas) eliminates esse voluerunt". Тота забрана була на моци єден час у Коцуре, а у Керестуре вона нїгда нє була запровадзена. Сташински тримал же ше на тих ноцних сходох младежи случую велї скандали и же од власцох треба вимагац же би ше тота забрана обновела и запровадзела (АПРК: Коцур, 29. 20. 1783). О два роки Сташински у новим писме Копчайови пише же ше уж штири роки трудзи "зоз казательнїци" забранїц прадки односно ноцни сходи младежи - "Quatuor jam annis desudo in conventiculis vulgo Fonó-ház impediendis instruendo ex Cathedra“, алє нїч нє помагало. Прето тримал же знова треба реаговац при жупанийских власцох и онєможлївиц дальше моралне и дружтвене препадованє тих двох руских заєднїцох. Вон у писме наводзи даскельо причини пре хтори трима же тоти сходи треба забранїц. Як перше, указує же ше там младеж морално губи, бо $є$ без надпатрунку старших. Як пошлїдок такого розпусного живота младежи, по його прешвеченю, факт же у Коцуре у долїнох були найдзени двойо мертви вируцени лємцо народзени дзеци. Єдно найдзене охабене пред валалску хижу, та го вноци хлопи принєсли на парохию. Сташински бул прешвечени же то зробели дзивки же би на таки способ скриц "ганьбу". Крем того, вон наводзи же ше случую велї крадзи: дзивки крадню од мацерох, легинє од оцох, слугове од газдох - цо лєм можу, и одноша на тоти сходи, а там вец єдза, пию и так препро- 
вадзую цали ноци - 'Denique furta fiunt varii generis: gurantur filiae a matribus, filii a Parentibus, servi ab hospitibus, aut promiscue a quocunque, et conferant ad conventrivula, ibi apatur, pinsitur, melle etiam illinitur". На тоти сходи приходза и легинє цо вонка з валалу чуваю статок, охабяюци го вноци без надпатрунку же би блукал, та уж було досц статку потрацене. Легинє котри ору оставаю 3 коньми вноци на пасовиску, алє и вони часто охабяю конї и иду до валалу на забави, а конї оставаю сами и блукаю. Розуми ше, чкода и у тим же младеж, котра ноци препровадзує на забавох, през дзень нє за роботу. Окрем того, и вояци котри на квартиру у валалє правя вельки нєшор, бо цали ноци препровадзую у карчми и танцую (АПРК: Коцур, 14. 11. 1785).

У даєдних писмох на латинским язику Сташинского Копчайови уруцени слова або и виреченя на руским язику, як наприклад, кед пише же им син Антоний лєпше: "стараме ся, як го маме отлучити, кед слабо хце їсти" (АПРК: Коцур, 25. 10. 1789). Познєйше у єдним писме Петрови Лука вецей як пол бока пише по руски з (АПРК: Коцур, 12.11. 1795), а зачуване єдно його писмо котре цале писал Петрови по руски односно на мишанїни народного и церковнославянского язика з кирилку (АПРК: Коцур, 22. юния 1793). Писмо пре язик и правопис заслужує векшу увагу и анализу лингвистох, праве прето же є єдно з барз ридких зачуваних медзи Руснацами у Бачки з другей половки XVIII вику на тим язику.

3 анализованих приватних писмох видно яки були почежкосци и трошки вязани за одход дзецох односно младежи до стреднїх школох и на студиї, и вообще за путованя на длугши драги. Так Янко Копчаї мл. писал оцови Петрови 1814. року як путовал до Бечу на студиї теологиї. Путованє на кочу з Керестура до Пешту го коштало 35. форинти, а з Пешту до Бечу путовали три днї. На концу писма зазначел єдну интересантносц. Наводзи же кед у конвикту, дзе бул змесцени, колегове з Галичини и з Мукачевскей епархиї видзели хлєб хтори вон принєсол $з$ дому, барз ше чудовали яки то вельки и красни хлєб з Бачки, а вец и коментарує: цо би на то поведла Пишкорка (служнїца котра го упекла - заувага Я. Р.)? Могла би ше похвалїц же ше єй хлєбу чудовали у Бечу - "Quid ad hoc Piskorka dicet? Poterit se laudare, quod ejus panis Vienae fuerit admiraculi instar". (АПРК: Беч, 23. 11. 1814; Костельник 1998: 125).

Путованє и на кратшу драгу часто представяло вельки проблем: требало мац або найсц коч, добри конї, кочияша, а окремни проблем могла буц и подла хвиля и розмочени драги. У новембру 1795. року коцурски капелан Янко Радванї мал по якейшик "важней роботи" исц до Макова. Лука Сташинки у писме модлєл П. Копчая же би пришол до ньго же би ше порадзели як помогню младому капеланови пойсц на таку драгу. Сташински ше такой виправдовал же нє ма добри конї, лєм два слаби кобули, а нє ма анї кочияша, бо ше його слуга женї - 'Ego nec equos ad currum, nisi duas cabalas, neg etiam aurigam habeam, qua servus meus )...) uhorem ducit“, а чловеку треба помогнуц, и заскончує: "То якоси мусить быти, ми го так як сироту незохабиме” (АПРК: Коцур, 12. 11. 1795).

Зачуване єдно писмо Петра Копчая синови Янкови з 1808. року, кед тот бул у стреднєй школи у Калочи. У нїм оцец, вироятно одвитуюци на синово питанє, наводзи же у нїх пол мери масла кошта 1 форинт 30 грайцари. Оцец у писме на латинским язику уруцує и подаєдно виреченє по руски, алє пише з латиницу. Так спомина же ма другу служнїцу: „,ale to trupacsok veliki nezna нїчъ”. 
Спомина и о гдовици панїматки Гаднянскей: 'Gadnajszka hodit jak bludna ovcza, nema miszcza nigde“ (АПРК: Керестур, 26. 07. 1808).

Єден час Янко Копчаї мл. як млади священїк бул управитель маєтку Крижевского владичества Ткалец и о тим досц обширно пише свойому оцови. У писме спомина же на хованю його предходнїка на тей длужносци були и клерики Руснаци Андрий Балог (Миз 2016: 36-37) и Дюра Шовш (Миз 2016: 342 343). Писмо писане на латинским язику, алє на концу виреченє по руски, дзе Янко наводзи же на маєтку будзе и за оца "мало татарки за кашу, и доброй сливовици до 10 акови” (АПРК: без наводзеня места и датума, 1818).

Янко Копчаї мл. як школяр висшей латинскей школи у Калочи 1808. року достал писмо од школского приятеля Яноша Соколи зоз Сегедину на латинским язику котре прави раритет у приватней преписки на латинским язику котру зме анализовали - полне є вилївох медзисобней легиньскей любови: 'De te somnio, tu mihi videris in somnio penes me esse (...) si videres meum cor quam turbulentum, et inquietum sit propter tui““ (АПРК: Фелшеварош, Сегедин, 19. 06. 1808).

За даєдни писма знаме хто их писал, алє лєм з векшу або меншу вироятносцу мож предпоставиц кому су писани. Так за писмо Луки Сташинского, насловене 303 "(...) in Spiritu Fili mihi Clarissime“ - у Духу сине мой мили, найвироятнєйше написане богословови Янкови Радваньови, котри бул на студийох у Загребу (Миз 2016: 263). Сташински у писме як прави "духовни оцец" висловює свою бригу и потримовку младому богословови же би ше цо пилнєйше пошвецел студийом, же би дзбал о своїм моралним напредованю и же би бул послушни своїм надредзеним. Спомина и же умар коцурски учитель: гоч нє наводзи мено и презвиско, очиглядно слово о учительови Андрийови Гочови, котри умар 4. януара 1791. року (Цап 1996: 41-44). Преноши му поздрав и од коцурского капелана Василия Бесерминя (Миз 2016: 41) (АПРК: Коцур, 24. 02, 1791).

Медзи писмами котри адресовани на П. Копчая находза ше два послати 3 Макова, од його дзивки Ани и жеца Стефана Силваши. Ана, наймладше од Петрових пецерих дзецох, народзена 1792. року, повинчала ше у Керестуре 28.

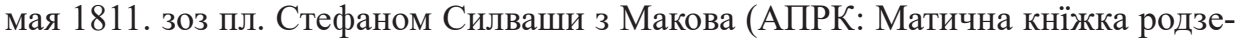
них, винчаних и умартих од 1779 р.). У писме з 1811. року повидомюю же ше щешлїво врацели дому и дзекую оцови за шицку госцолюбивосц и источашнє го поволую же би 16. септембра пришол до нїх зоз сином Янком на оберачку грозна - "16-a mensis curr[entis] 7-bris apud nos Celebraturas Vindemias, humiliatione sua dignos facere, et huc cum fratre nostro Joanne venire" (АПРК: Мако, 5. 09. 1811). У другим писме дзивка и жец висловюю оцови свою радосц же брат Янко "послухал глас Божи" и пошол на студиї теологиї до Бечу, одкаль уж од нього достали писмо. За себе наводза же су добре, лєм им дзивчатко Мария уж три днї хора. На концу поздравяю оца и наводза же пре жиму и нєлєгке путованє до яри вироятно нє приду до Керестура (АПРК: Мако, 11. 12. 1814).

И вельо познєйше, аж и у XX вику, латински язик голєм часточно оставал присутни у комуникациї медзи руским священством баржей як якиш вид "тайного язика" - у ситуацийох кед на векших сходох дзе були присутни и представнїки цивилох священїки мали потребу дацо прегвариц так же би гевти други нє розумели. 
Як шлїд дакедишнєй пракси епистоларней комуникациї руских священїкох односно рускей интелигенциї на латинским язику и писмо Михайла Мункачия, библиотекара Библиотеки Мадярскей акадамиї наукох и уметноссцох 31940. року керестурскому парохови. Цале є писане на писацей машинки на латинским язику, алє на концу поздрав по руски: "Pozdrav prekrasni od šerca“" (Ramac 2014: 375).

На концу можеме констатовац же латински язик як официйни у державней администрациї и як язик у найвекшей мири заступени у стреднїм и високим образованю, углавним бул язик официйней администрациї и комуникациї и у Мукачевскей и Крижевскей епархиї, а найчастейше бул заступени и у приватней кореспонденциї русинского/руского священства тих двох епархийох при концу XVIII и на початку XIX вика. Русински, карпаторусински або вариянти церковнославянского язика у такей преписки вельо ридши, або су присутни лєм як интерполациї - подаєдно виреченє або окремни слова. Анализована преписка значна и пре факт же дава богатство податкох 3 приватного, дружтвеного, церковно-религийного, образовного и културного живота Русинох/Руснацох Мукачевскей и Крижевскей епархиї.

\section{Цитована литература}

Гнатюк, Володимир. «Рускі оселї в Бачцї. (В Полудневій Угорщині)». Записки Наукового Товариства ім. Шевченка, т. XXII, 1898: 1-58.

[Gnatûk, Volodimir. «Ruskì oselï v Bačcï. (V Poludnevìj Ugorŝinì)». Zapiski Naukovogo Tovaristva ìm. Ševčenka, t. XXII, 1898: 1-58]

Гнатюк, Володимир. Угроруські духовні вірші. т. І. Львів, 1902. Латяк, Д. (ред.), Нови Сад: Руске слово, 1985.

[Gnatûk, Volodimir. Ugroruskì duhovnì vìršì. t. I. L'vìv, 1902. D. Latâk (red.), Novi Sad: Ruske slovo, 1985]

Гнатюк, Володимир. Етнографічні матеріяли з Угорської Руси. Байки, лєгенди, істор.перекази, новелї, анегдоти - з Бачки. т. ІІ. Львів, 1911. Латяк, Д. (ред.), Нови Сад: Руске слово, 1986а.

[Gnatûk, Volodimir. Etnografičnì materiâli z Ugors'koï Rusi. Bajki, lêgendi, ìstor. perekazi, novelï, aneg’doti - z Bački. t. II. L'vìv, 1911. Latâk, D. (red.), Novi Sad: Ruske slovo, 1986a]

Гнатюк, Володимир. Етнографічні матеріяли з Угорської Руси. Казки з Бачки.т. III. Львів, 1910. Латяк (ред.). Нови Сад: Руске слово, 19866.

[Gnatûk, Volodimir. Etnografičnì materiâli z Ugors'koï Rusi. Kazki z Bački.t. III. L'ìv, 1910. Latâk, D. (red.). Novi Sad: Ruske slovo, 1986b]

Гнатюк, Володимир. Етнографічні матеріяли з Угорської Руси. І. Західні угорсько-руські комітати. II. Бач- Бодрогський комітат. т. IV. Львів, 1910. Латяк, Д. (ред.). Нови Сад: Руске слово, 1986в.

[Gnatûk, Volodimir. Etnog’afičnì materiâli z Ugors'koï Rusi. I. Zahìdnì ugors'korus'kì komitati. II. Bač- Bodrogs' kij komitat. t. IV. L'vìv, 1910. Latâk, D. (red.). Novi Sad: Ruske slovo, 1986v]

Гнатюк, Володимир. Етнографични материяли з Угорскей Руси. Розправи и статї 
оРуснацох Бачки, Сриму и Славониї. т. V. Нови Сад: Руске слово, 1988.

[Gnatûk, Volodimir. Etnografični materiâli z Ugorskej Rusi. Rozpravi i statï o Rusnacoh Bački, Srimu i Slavoniï. t. V. Novi Sad: Ruske slovo, 1988]

Дуличенко, Александер. Jugoslavo-Ruthenica. Роботи з рускей филологиї. Нови Сад: Руске слово, 1995.

[Duličenko, Aleksander. Jugoslavo-Ruthenica. Roboti z ruskej filologiii. Novi Sad: Ruske slovo, 1995]

Дуличенко, Александер. Кнїжка о руским язику. Увод до рускей филологиї у документох икоментарох. Нови Сад: Дружтво за руски язик, литературу и културу, 2002.

[Duličenko, Aleksander. Knïžka o ruskim âziku. Uvod do ruskej filologiï u dokumentoh ikomentaroh. Novi Sad: Družtvo za ruski âzik, literaturu i kulturu, 2002]

Дуличенко, Александер. Письменность и литературные языки Карпатской Руси (XV-XX вв.). Ужгород: Издательство В. Падяка, 2008.

[Duličenko, Aleksander. Pis'mennost' i literaturnыe âzыki Karpatskoj Rusi (XV-XX vv.). Užgorod: Izdatel'stvo V. Padâka, 2008]

Дуличенко, Александер. Jugoslavo-Ruthenica II. Роботи з рускей филологиї и историї. Нови Сад: Филозофски факултет Нови Сад - Руске слово, 2009.

[Duličenko, Aleksander. Jugoslavo-Ruthenica II. Roboti z ruskej filologiï i istoriï. Novi Sad: Filozofski fakultet Novi Sad - Ruske slovo, 2009]

Ковач, Михайхло. «Розвой писаного слова и сучасна видавательна дїялносц у нас». Нова думка, 4. Вуковар: Союз русинів-українців Хорватії, 1973, 41-45.

[Kovač, Mihajhlo. «Rozvoj pisanogo slova i sučasna vidavatel'na diâlnosc u nas». Nova dumka, 4. Vukovar: Soûz rusinìv-ukraïncìv Horvatiï, 1973, 41-45]

Ковач, Михайло. «Шлїдами зазберовачох народних духовних скарбох у нас». Нова думка, 16. Вуковар: Союз русинів- українців Хорватії, 1977, 49-46.

[Kovač, Mihajlo. «Šlïdami zazberovačoh narodnih duhovnih skarboh u nas». Nova dumka, 16. Vukovar: Soûz rusinìv-ukraïncìv Horvatiï, 1977, 49-46]

Костельник, Гавриїл. Liber memorabilium грекокатолїцкей парохиї бачкерестурскей. Нови Сад: Союз Руснацох и Українцох Югославиї, 1998.

[Kostel'nik, Gavriïl. Liber memorabilium grekokatolïckej parohiï bačkeresturskej. Novi Sad: Soûz Rusnacoh i Ukraïncoh Ûgoslaviï, 1998]

Миз, Роман. Священїки дакедишнього Осєцкого викарията. Нови Сад Петроварадин: Парохия св. Петра и Павла Нови Сад - „Махіта“ - друкарня и видавательна хижа, Петроварадин, 2016.

[Miz, Roman. Svâsenïki dakedišn'ogo Osêckogo vikariâta. Novi Sad - Petrovaradin: Parohiâ sv. Petra i Pavla Novi Sad - „Maxima“ - drukarnâ i vidavatelna hiža, Petrovaradin, 2016]

Миз; Роман. «Спомин вични керестурски». Християнский календар 1971 (за вирних Крижевацкей епархиї), Руски Керестур: Войводянски викарият, 90-96.

[Miz; Roman. «Spomin vični keresturski». Hristiânskij kalendar 1971 (za virnih Križevackej eparhii), Ruski Kerestur: Vojvodânski vikariât, 90-96]

Пишчевић, Симеон. Мемоари. Нови Сад-Београд, 1972.

[Piščević, Simeon. Memoari. Novi Sad-Beograd, 1972]

Рамач Фурман Анамария. «Особлївосци консонатизма єдней рускей рукописней кнїжки з початку XX вику». Шветлосц, 4/2019. Нови Сад: Руске слово, 2019, 25-45.

[Ramač Furman Anamariâ. «Osoblïvosci konsonatizma êdnej ruskej rukopisnej knižki z počatku XX viku». Švetlosc, 4/2019. Novi Sad: Ruske slovo, 2019, 25-45] 
Рамач, Янко. «Тексти апокрифа ”Хождениє Богородици по муках” у руских рукописних зборнїкох». Шветлосц, 1/2011. Нови Сад: Руске слово, 2011, 49-70.

[Ramač, Ânko. «Teksti apokrifa "Hoždeniê Bogorodici po mukah" u ruskih rukopisnih zbornikkoh». Švetlosc, 1/2011. Novi Sad: Ruske slovo, 2011, 49-70]

Рамач, Янко. «Матеріали до вивчення апокрифів з рукописних збірок русинів Південної Угорщини (XIX ст)». Проблеми славянознавства/Problems of Slavonic studies, Випуск/Issue 65. Лівів - Львівський національний університет, 2016, 158 166.

[Ramač, Ânko. «Materìali do vivčennâ apokrifìv z rukopisnih zbìrok rusinìv Pìvdennoï Ugorŝini (XIX st)». Problemi slavânoznavstva/Problems of Slavonic studies, Vipusk/ Issue 65. Lìvìv - L'vìvs'kij nacìonal'nij unìversitet, 2016, 158-166]

Рамач, Јанко. «Почеци националног препорода Русина у Јужној Угарској у првој половини19. века». Годишњак филозофског факултета у Новом Саду, књ. XXXV-1, Филозофски факултет Нови Сад, Нови Сад, 2010, 255-266.

[Ramač, Janko. «Počeci nacionalnog preporoda Rusina u Južnoj Ugarskoj u prvoj polovini19. veka». Godišnjak filozofskog fakulteta u Novom Sadu, knj. XXXV-1, Filozofski fakultet Novi Sad, Novi Sad, 2010, 255-266]

Рамач, Янко. «Подоби Христа, апостолохи святих у апокрифох Руснацох у Южней Угорскей». [У:] А. Дуличенко, - М. Номати (ред). Славянская микрофилология. Slavica Tartuensia XI - Slavic Euroasian Studies 34. Sapporo - Tartu: Slavic-Euroasian Research Center - Slaavi Filoloogia Osakond, 2018, 273-289.

[Ramač, Ânko. «Podobi Hrista, apostolohi svâtih u apokrifoh Rusnacoh u Ûžnej Ugorskej». [U:] A. Duličenko, - M. Nomati (red). Slavânskaâ mikrofilologiâ. Slavica Tartuensia XI - Slavic Euroasian Studies 34. Sapporo - Tartu: Slavic-Euroasian Research Center - Slaavi Filoloogia Osakond, 2018, 273-289]

Рамач, Юлиян. Граматика руского язика. Београд: Завод за уџбенике и наставна средства, 2002.

[Ramač, Ûliân. Gramatika ruskogo âzika. Beograd: Zavod za udžbenike i nastavna sredstva, 2002]

Тамаш, Юлиян. История рускей литератури, Београд: Завод за уџбенике и наставна средства. 1997.

[Tamaš, Ûliân. Istoriâ ruskej literaturi, Beograd: Zavod za udžbenike i nastavna sredstva. 1997]

Франко, Іван. Апокрифи і легенди з українських рукописів. т. II, Апокрифи новозавітні. А. Апокрифічні евангелія. Львів, 1899. Львів: Львівський національний університет, 2006.

[Franko, İvan. Apokrifi ì legendi z ukraïns'kih rukopisìv. t. II, Apokrifi novozavìtnì. A. Apokrifičnì evangeliâ. L'vìv, 1899. L'vìv: L'vìvs'kij nacìonal'nij unìversitet, 2006]

Франко, Іван. Апокрифи і легенди з українських рукописів. т. IV. Апокрифи есхатологічні. Львів, 1906. Львів: Львівський національний університет, 2006.

[Franko, İvan. Apokrifi ì legendi z ukraïns'kih rukopisìv. t. IV. Apokrifi eshatologìčnì. L'vìv, 1906. L'vìv: L'vìvs'kij nacìonal'nij unìversitet, 2006]

Удвари, Иштван. «Нєпознате писмо Георгия Росия на мадярску Горнїцу». Шветлосц, 2/1989. Нови Сад: Руске слово, 1989, 246-258.

[Udvari, Ištvan. «Nêpoznate pismo Georgiâ Rosiâ na madârsku Gornïcu». Švetlosc, 2/1989. Novi Sad: Ruske slovo, 1989, 246-258]

Удвари, Иштван. «Русини у XVIII вику и Андрий Бачински» (1-2). Шветлосц, 1, 
2/1991, Нови Сад, 1991, 65-81 44-66.

[Udvari, Ištvan. «Rusini u XVIII viku i Andrij Bačinski» (1-2). Švetlosc, 1, 2/1991, Novi Sad, 1991, 65-81 44-66]

Удвари, Иштван. «Школованє русинскей церковней интелигенциї у XVIII вику (место и язик)». Studia ruthenica, 3, Нови Сад, 1992-1993, 167-173.

[Udvari, Ištvan. «Školovanê rusinskej cerkovnej inteligenciï u XVIII viku (mesto i âzik)». Studia ruthenica, 3, Novi Sad, 1992-1993, 167-173]

Удвари, Іштван. Кириличні уббіжникы мукачовського єпископа Андрія Бачинського. Нїредьгаза, 2002.

[Udvari, İštvan. Kiriličnì ubbìžnikы mukačovs'kogo êpiskopa Andrìâ Bačins'kogo. Nïred'gaza, 2002]

Шлепецький, Андрій. «Мукачівський єпіскоп Андрій Федорович Бачинський та його послання». Науковий збірник Музею української культури у Свиднику, 3, Пряшів, 1967, 223-242.

[Šlepec'kij, Andrìj. «Mukačìvs'kij êpìskop Andrìj Fedorovič Bačins'kij ta jogo poslannâ». Naukovij zbìrnik Muzeû ukraïns'koï kul'turi u Svidniku, 3, Prâšìv, 1967, 223-242]

Lucskay, Michael. Historia Carpato-Ruthenorum, t. 4. Науковий збірник Музею української культури у Свиднику, 18. Пряшів, 1992, 63-153.

[Lucskay, Michael. Historia Carpato-Ruthenorum, t. 4». Naukovij zbìrnik Muzeû ukraïns'koï kul'turi u Svidniku, 18, Prâšìv, 1992, 63-153]

Ramač, Janko. «Mihajlo Munkači - bibliotekar, profesor, prevodilac, lingvista». [U:] Živančević, I. (red.). Susret kultura. Zbornik radova sa Sedmog međunarodnog interdisciplinarnog simpozijuma. Novi Sad: Filozofski fakultet, 2014, 369-376.

\section{Жридла}

Архив Парохиї у Руским Керестуре (АПРК) - приватни писма без сигнатурох и матрикули кресцених, винчаних и умартих.

[Arhiv Parohiï u Ruskim Keresture (APRK) - privatni pisma bez signaturoh i matrikuli krescenih, vinčanih i umartih] 


\title{
Janko Ramač
}

\section{THE EPISTOLARY LEGACY OF RUTHENIAN PRIESTS IN BACKA IN THE LATIN LANGUAGE IN THE SECOND HALF OF THE $18^{\text {th }}$ AND AT THE BEGINNING OF THE $19^{\text {th }}$ CENTURY}

\begin{abstract}
Summary
Analyzing a large part of private correspondence in the Latin language between a few priests, which was preserved in the Archive of the Greek Catholic parish in Ruski Krstur, the author shows that in the specified period, the Latin language was much more common in this kind of correspondence than the vernacular or the literary Church Slavonic language. The main reason for the dominant use of the Latin language in this correspondence was that both the senders and the recipients were fluent in Latin, which they had learned well in secondary and higher education. They used their mother tongue only in communication with the people and in private conversation, and the Church Slavonic language in religious service and in strictly religious communication. In their private correspondence they sometimes, but rarely, used a mixture of the vernacular with some elements of the Church Slavonic language.

The content of the researched correspondence is very important because it gives a lot of information not only on the private life of the priests and their closest circles, but also on the religious, educational, cultural, social and economic life of the Ruthenians in Bačka and those living within the Diocese of Mukačevo.

Keywords: Ruthenians in Southern Hungary, Petro Kopcaji, Luka Stasinski, Janko Kopcaji Sr, Janko Kopcaji Jr, Greek Catholics, private correspondence, Latin language, Ruthenian language.
\end{abstract}

